\title{
Criterios inspiradores de la reforma del proceso de nulidad*
}

\section{Criteria for the Reform of the Nullity Process}

\author{
María J. Roca FERnándeZ \\ Catedrática de Derecho Eclesiástico del Estado \\ Universidad Complutense de Madrid \\ orcid 0000-0002-8827-5177 \\ mjroca@der.ucm.es
}

Resumen: En este trabajo se exponen los medios técnicos a través de los cuales se ha llevado a cabo cada uno de esos criterios, y en qué medida se puede considerar que los medios empleados conducen a alcanzar el objetivo pretendido (la celeridad y gratuidad de los procesos de nulidad, con el fin de servir mejor a la salvación de las almas). Las medidas tendentes a reforzar la responsabilidad del Obispo en su diócesis son claras y eficaces para obtener ese fin: tanto por los procesos en los que actúa como juez, como por la mayor discrecionalidad de la que goza para nombrar juez único y jueces laicos (sin compartir su responsabilidad con la Conferencia Episcopal). Ahora bien, esta mayor discrecionalidad en el nombramiento de jueces, puede ser considerada también como medida que favorece la colegialidad episcopal menos que las previsiones anteriores a la reforma. A partir de la reforma cada Obispo diocesano goza de mayor autonomía en su diócesis, sin necesidad de contar con la aprobación de la Conferencia episcopal, que es una estructura de gobierno, al servicio de la colegialidad y la comunión episcopal.

Palabras clave: Proceso ordinario de nulidad, Proceso breve ante el Obispo, Apelación.
Abstract: This paper presents the technical means by which each of the criteria has been framed, and to what extent the means employed may be regarded as leading to the achievement of the desired objective (efficiency and cost-free nature of nullity processes, so as to better serve the salvation of souls). Measures that strengthen the responsibility of the bishop in his diocese are clear and effective in achieving this end: both in the processes in which he acts as a judge and in the greater discretion he enjoys in appointing a single judge and lay judges, without sharing such responsibility with the Episcopal Conference. However, greater discretion in the appointment of judges may also be read as a measure that favors episcopal collegiality less than was foreseen prior to the reform. Following the reform, each diocesan Bishop enjoys greater autonomy in his diocese, with no requirement of approval from the Episcopal Conference, which is a structure of government at the service of episcopal collegiality and communion.

Keywords: Ordinary Process of Nullity, Brief Process Before the Bishop, Appeal.

\footnotetext{
* Deseo agradecer su gentileza al Decano del Tribunal de la Nunciatura de Madrid, Dr. Carlos Morán, al Vicario Judicial y catedrático de la Universidad de Barcelona, Dr. Santiago Bueno Salinas, y al Juez del Tribunal de la Diócesis de Sigüenza-Guadalajara, Dr. Fernando Lozano por su valiosa ayuda, facilitándome la visión práctica de la aplicación del M.P. en los Tribunales de su competencia.
} 


\section{INTRODUCCIÓN: LOS CRITERIOS INSPIRADORES SEGÚN EL TEXTO NORMATIVO}

L 1 texto del motu proprio Mitis Iudex (en adelante, MI) anota cuáles han sido los criterios inspiradores de la reforma ${ }^{1}$. En este trabajo se exponen los medios técnicos a través de los cuales se ha llevado a cabo cada uno de esos criterios, y en qué medida se puede considerar que los medios empleados conducen a alcanzar el objetivo pretendido (la celeridad y gratuidad de los procesos de nulidad, con el fin de servir mejor a la salvación de las almas). Se intentará evitar tanto el dramatismo sobre esta «refundación $»^{2}$ de los procesos canónicos de nulidad como la euforia. En mi opinión, ni hay motivos de alarma ni estamos ante el único o el mejor modo de ejercitar la potestad judicial, de vivir la colegialidad episcopal o la justicia entre las partes. Estamos ante una reforma que ha entrado en vigor, y deseamos contribuir a su correcta aplicación.

\section{UNA SOLA SENTENCIA EN FAVOR DE LA NULIDAD ES EJECUTIVA}

Esta medida, de la que ya se venía discutiendo en la doctrina años atrás, y que estuvo vigente en las normas dadas a la Conferencia Episcopal de los Estados Unidos de América, y luego extendidas a otros países, en los años del post-concilio ${ }^{3}$, presenta la ventaja de su claridad y simplicidad a la hora de ser aplicada. Por ello, facilitará uno de los fines principales de la reforma: la celeridad de los procesos. Se ha puesto de manifiesto que la supresión de la doble

${ }^{1}$ Proemio del MI: «La mayoría de mis hermanos en el Episcopado, reunidos en el reciente Sínodo Extraordinario, demandó procesos más rápidos y accesibles. En total sintonía con dichos deseos, he decidido dar mediante este Motu Proprio disposiciones con las que se favorezca, no la nulidad de los matrimonios, sino la celeridad de los procesos y, no en menor grado una adecuada sencillez».

2 Éste es el término empleado por el Decano de la Rota Romana para referirse a la reforma. A esta expresión se adhiere para calificarla J. LLOBELL, El ejercicio personal de la potestad judicial del Obispo diocesano. Algunas consideraciones preliminares al M.p. «Mitis Iudex» y al M.p. «Mitis et Misericors», Revista General de Derecho Canónico y Eclesiástico del Estado 41 (2016) 1. J. LlobeLL, Cuestiones acerca de la apelación y la cosa juzgada en el nuevo proceso de nulidad del matrimonio, Anuario de Derecho Canónico supl. 5 (2016) 54.

3 Normas especiales ad experimentum dadas por el Romano Pontífice Pablo VI a la Conferencia Episcopal de Estados Unidos en 1970, publicadas en X. OcHOA, Leges Ecclesiae post Codicem Iuris Canonicae editae, vol. 4, Romae 1974, n. 3885, col. 5877; n. 3920, col 5918, n. 3943, col. 5962. A. M. López Medina, Precedentes mediatos e inmediatos de una esperada reforma de las causas matrimoniales, Revista General de Derecho Canónico y Eclesiástico del Estado 40 (2016) 11-14. 
conforme y la instauración del proceso breve ante el Obispo son las dos medidas que mayor favorecen la celeridad de los procesos canónicos de nulidad matrimonial ${ }^{4}$. Como es sabido, la «doble sentencia conforme» tiene su origen en la Iglesia en la Constitución apostólica Dei Miseratione, de 1741 y, por tanto, no es de Derecho divino. Es claro que podía suprimirse. Ya antes de la reforma del Romano Pontífice Francisco, se suprimió ad experimentum, durante tres años, la exigencia de la doble sentencia conforme en la Rota Romana ${ }^{5}$. Esta facultad especial fue interpretada -más allá de lo expresado en el texto que la concedía- como inapelabilidad de las sentencias. Después de la reforma del motu proprio MI no parece posible seguir manteniendo esa interpretación ${ }^{6}$.

La supresión de la exigencia de la doble sentencia conforme para que el fallo sea ejecutivo, no afecta a la necesidad de que el juez decida a favor de la nulidad sólo cuando haya alcanzado la certeza moral $^{7}$, también cuando la cau-

${ }^{4}$ C. PeÑa García, Agilización de los procesos canónicos de nulidad matrimonial: de las propuestas presinodales al motu proprio Mitis Iudex Dominus Iesus y retos pendientes tras la reforma, Ius Canonicum 56 (2016) 55. R. RODRíGUEz CHACÓN, La ejecutividad de las sentencias afirmativas de nulidad de matrimonio no apeladas, Revista General de Derecho Canónico y Eclesiástico del Estado 40 (2016) 11-16, y 20, «aun dándose esa segunda instancia en su versión abreviada o aligerada, siempre se producía un suplemento de costo económico, de esfuerzos y de tiempo invertido que en la mayoría de los casos no se justificaba cuando, sencillamente, nadie había apelado una sentencia porque todos los intervinientes la consideraban correcta y justa». En opinión de S. BuENo SaLinas, La reforma de los procesos canónicos de declaración de nulidad de matrimonio. La celeridad del proceso, Revista General de Derecho Canónico y Eclesiástico del Estado 40 (2016) 3, la supresión de la doble conforme es la mayor novedad del MI.

5 R. Rodríguez Chacón, El Rescriptum ex audientia SS. MI. de 11 de febrero de 2013, Revista General de Derecho Canónico y Eclesiástico del Estado 34 (2014); C. PEÑa GarCÍA, «Facultades especiales» del Decano y novedades procesales en la Rota Romana. ¿Hacia una renovación de las causas de nulidad matrimonial?, Estudios Eclesiásticos 88 (2013) 767 y ss. J. LlobELL, Novità procedurali riguardanti la Rota Romana: le facoltà speciali, Stato Chiese e pluralismo confessionale 32 (2013), (www.statochiese.it).

${ }^{6}$ R. Rodríguez CHACón, La ejecutividad de las sentencias afirmativas de nulidad de matrimonio no apeladas, Revista General de Derecho Canónico y Eclesiástico del Estado 40 (2016) 9. R. RodRÍGUEz Chacón, El Rescriptum ex audientia SS. MI. de 11 de febrero de 2013..., 16-18. J. LlObELL, Novità procedurali riguardanti la Rota Romana: le facoltà speciali..., 7.

7 Sobre la certeza moral del juez, sigue siendo de obligada referencia el Discurso a la Rota romana de Pío XII, pronunciado el día 1 de octubre de 1942. También el Santo Padre Francisco, en su Discurso a los participantes en el Congreso Internacional organizado por la Facultad de Derecho Canónico de la Pontificia Universidad Gregoriana indicó que «la meta del proceso mismo, o sea la certeza moral: ella requiere que quede totalmente excluida cualquier prudente duda positiva de error, aunque no está excluida la mera posibilidad de lo contrario (cfr. Dignitas connubii, art. $247 \$ 2$ )». De la abundante bibliografía al respecto, pueden verse: R. NAVARRO VALLS, Los fundamentos de la sentencia canónica, Ius canonicum 15 (1975) especialmente 322-327. P. A. BoNNET, De iudicis sententia ac de certitudine morali, Periodica 75 (1986) 61-100. Z. GROCHOLEWSKI, La certezza morale come chiave di lettura delle norme processuali, Ius Eclesiae 9 (1997) 417-450. 
sa es tramitada por el proceso brevior ${ }^{8}$. La reforma introducida por el MI no recoge la llamada «certeza prevalente» ${ }^{9}$ de las normas americanas, y en la medida en que es posible que se ejecute la nulidad de un solo juez, incrementa notablemente la responsabilidad del juez en la decisión ${ }^{10}$.

Asimismo, la supresión de la doble conforme no supone que la sentencia afirmativa de la nulidad no sea apelable ${ }^{11}$. Se concede a las partes y al defensor del vínculo el derecho de apelación. La apelación ha cambiado su naturaleza: ha dejado de ser un deber que operaba ope legis en muchos casos, y ha pasado a ser un derecho de las partes, que pueden ejercitar o no, según consideren oportuno.

Puede afirmarse que esta reforma supone una muestra de confianza en el trabajo de los tribunales inferiores ${ }^{12}$. ¿En qué modo afectará esta medida a la elaboración de unos criterios jurisprudenciales uniformes, que era una de las razones por la que se exigía la doble conforme ${ }^{13}$ ? Los criterios para ponderar

P. ERDÖ, La certeza morale nella pronuncia del giudice. Problemi attuali, Periodica 87 (1998) 81-104. J. LLOBELl, La certeza morale nel proceso canonico, Il Diritto ecclesiastico 109/1 (1998) 758-802. M. Á. OrTiZ, Le dichiarazioni delle parti e la certezza morale, Ius Ecclesiae 18 (2006) 387-416. J. Huber, Die moralische Gewissheit des Richters (c. 1608 CIC/1983), De Processibus matrimonialibus 21/22 (2014/15) 377-396. Hemos aportado algunas consideraciones acerca de la certeza moral con en el comentario a la Sentencia de la Rota Romana 158/2010 c. Erlebach, 26 de noviembre de 2010. Traducción al castellano de $\mathrm{M}^{\mathrm{a}} \mathrm{J}$. Roca y R. Rodríguez CHACón, Comentario de R. Rodríguez Chacón. Reflexión sobre la certeza moral (690-693) de María 7. Roca, Revista Española de Derecho Canónico 70 (2013) 655-693.

8 J. Llobell, Cuestiones acerca de la apelación y la cosa juzgada..., 58.

9 R. Rodríguez CHACón, La ejecutividad de las sentencias afirmativas de nulidad de matrimonio no apeladas..., 23, nota 65 hace constar que apareció en el n. 21 de las mencionadas normas.

10 R. Rodríguez Chacón, La ejecutividad de las sentencias afirmativas de nulidad..., 26, «la nueva regulación aumenta la responsabilidad del juez, que no podrá contar con otro tribunal superior haya de volver a someter a examen necesariamente y siempre los elementos probatorios y de convicción que él ha estudiado y valorado en su instancia». Ibid., nota 74, considera que las apelaciones siempre deberían ser un motivo de mayor tranquilidad para los jueces.

11 R. Rodríguez CHACÓN, La ejecutividad de las sentencias afirmativas de nulidad de matrimonio no apeladas, Revista General de Derecho Canónico y Eclesiástico del Estado 40 (2016). R. RodRíGUEZ-OCAÑA, Mitis Iudex: Fuero competente y sistema de apelaciones, Ius Canonicum 56 (2016) 105134. J. LlobelL, Cuestiones acerca de la apelación y la cosa juzgada..., 70-74, habla de una «revalorización» del derecho de apelación.

12 R. Rodríguez CHACón, Antecedentes, estructura y valor jurídico en el sistema normativo canónico de los dos Motu Propio de 15 de agosto de 2015 y sus normas anejas, en M. E. Olmos OrTega (ed.), Procesos de nulidad matrimonial tras la reforma del Papa Francisco, Madrid 2016, 58, considera que en la nueva regulación hay un principio subyacente «un principio de valiente aunque arriesgada apuesta por la responsabilidad y la confianza». R. RODRÍGUEZ CHACÓN, La ejecutividad de las sentencias afirmativas de nulidad..., 10 y 20. S. BUENO SALINAS, La reforma de los procesos canónicos de declaración de nulidad de matrimonio. La celeridad del proceso..., 4.

13 A tenor del art. $126 \$ 1$, la Rota Romana tiene encomendada la unidad de la jurisprudencia. Este munus se recuerda en el Subsidio aplicativo, 49, al explicar la mens del Pontífice sobre la refor- 
los efectos de esta medida necesitan una perspectiva temporal de mayor distancia respecto a su entrada en vigor. Pero en todo caso, son parámetros de ponderación distintos al fin principal de la reforma: la celeridad del proceso de nulidad ${ }^{14}$. La supresión de la doble conformidad supone que ahora puede obtenerse una sentencia firme en un plazo que oscila entre cuatro meses y un año ${ }^{15}$. La reforma agiliza ciertamente la primera instancia, pero no la segunda. En el régimen anterior se preveía la confirmación por decreto. Ahora, si hay apelación, el tribunal superior está supeditado a las peticiones que haya hecho el apelante ${ }^{16}$, y la apelación que se tramita por el proceso contencioso ordinario de nulidad, se decide mediante sentencia.

\section{El JUEZ ÚNICO, BAJO LA RESPONSABILIDAD DEL OBISPO}

La posibilidad de que las causas de nulidad matrimonial se tramiten ante un único juez (no ante un tribunal colegiado), era otra de las principales propuestas de reforma que estaban en estudio ${ }^{17}$. Así en el preámbulo del MI se anota: «la constitución del juez único en primera instancia, siempre clérigo,

ma de los procesos matrimoniales. G. BoNI, La recente riforma del proceso di nullità matrimoniale. Problemi, criticità, dubbi (parte terza), Stato Chiese e pluralismo confessionale 11 (2016) 39, www.statochiese.it, anota que la entrada en vigor del MI supondrá una dificultad para el cumplimiento de este encargo y la asignación de un protagonismo inédito a los tribunales inferiores. El Santo Padre Francisco en la Ex. Ap. Amoris Laetitia, n. 244, hace notar la «necesidad de hacer más accesibles y ágiles posiblemente totalmente gratuitos, los procedimientos para las causas de nulidad. La lentitud de los procesos irrita y cansa a la gente». Consideraciones sugerentes acerca de la celeridad de los procesos matrimoniales, pueden verse en O. FumaGaldi CARULLI, Celerità della via giudiziaria e pastorale di prossimità nella riforma del processo matrimoniale canonico, Ius Vita e Pensiero, publicado el 1-VI-2016 accesible en http://jus.vitaepensiero.it/ news-papers-celerita-della-via-giudiziaria-e-pastorale-di-prossimita-nella-riforma-del-processo-matrimoniale-canonico-4660.html. Consulta del 22-X-2016. Hasta donde conocemos, la información anual que la Signatura Apostólica pide a todos los Tribunales eclesiásticos, no contiene la indicación del dato de la duración de cada proceso tramitado ante ese Tribunal. Con fecha 9 de diciembre de 2016, la Signatura Apostólica ha remitido una Carta Circular (Prot. n. 51712/16 VT) a todos los Obispos moderadores de Tribunales eclesiásticos con nuevas normas para la elaboración del informa anual de su actividad. En ellas, si se pide información sobre la duración de los procesos.

15 S. Bueno Salinas, La reforma de los procesos canónicos de declaración de nulidad de matrimonio. La celeridad del proceso..., 5 .

16 S. Bueno Salinas, La reforma de los procesos canónicos de declaración de nulidad de matrimonio. La celeridad del proceso..., 7.

17 G. BonI, La recente riforma del proceso di nullità matrimoniale. Problemi, criticità, dubbi (parte prima), Stato Chiese e pluralismo confessionale 9 (2016) 57, www.statochiese.it, cfr. la bibliografía citada en la nota 160 . 
se deja a la responsabilidad del Obispo, que en el ejercicio pastoral de la propia potestad judicial deberá asegurar que no se permita ningún laxismo».

La regla general, también después de la reforma, según lo que establece el nuevo c. $1673 \$ 3$ («las causas de nulidad de matrimonio se reservan a un colegio de tres jueces. Éste debe ser presidido por un juez clérigo, los demás jueces pueden ser también laicos») será que en las diócesis donde resulte posible, se sigan tramitando las casusas de nulidad ante tribunales colegiados. Ahora bien, a tenor del $\$ 4$ del mismo c. 1673 , «el Obispo Moderador, si no es posible constituir el tribunal colegial en la diócesis o en el tribunal cercano que ha sido elegido conforme al $\$ 2$, confíe las causas a un juez único, clérigo, que, donde sea posible, se asocie dos asesores de vida ejemplar, expertos en ciencias jurídicas o humanas, aprobados por el Obispo para esta tarea; al mismo juez único competen, salvo que resulte de modo diverso, las funciones atribuidas al colegio, al presidente o al ponente» ${ }^{18}$. Es decir, la novedad de la reforma en este punto más que en la posibilidad de tramitación ante el juez único en primera instancia -que ya se permitía en el c. $1425 \$ 4$-, es que ya no se requiere autorización de la Conferencia Episcopal, como venía siendo exigido hasta ahora ${ }^{19}$.

La posibilidad de que los obispos nombren jueces laicos -a tenor de lo previsto en el nuevo c. $1676 \$ 3$ - no supone que éstos puedan actuar como jueces únicos ${ }^{20}$. En este aspecto la novedad es que no se exige mayoría de jueces clérigos en el colegio, ni tampoco se precisa de la autorización de la Conferencia Episcopal, como venía siendo preceptivo antes de la reforma. Esta medida,

18 J. P. Beal, Mitis Iudex Canons 1671-1682, 1688-1691. A commentary, The Jurist 75 (2015) 478, anota que se trata de una secuencia ordenada. No son, por tanto, múltiples opciones para elegir entre ellas indistintamente.

$19 \ll$ Si no es posible constituir un tribunal colegial en el primer grado del juicio, la Conferencia Episcopal puede permitir que, mientras dure la imposibilidad, el Obispo encomiende las casusas a un único juez clérigo, el cual, donde sea posible, se valga de la colaboración de un asesor y de un auditor».

20 C. PeÑa García, La reforma de los procesos canónicos de nulidad matrimonial: el Motu Proprio 'Mitis Iudex Dominus Iesus', Estudios eclesiásticos 90 (2015) 644, nota 33, anota: «como se señaló en el proceso codificador, la potestad judicial no requiere de suyo la potestad de orden, por lo que no se ven obstáculos de peso a que se permita el nombramiento de laicos como jueces, ni siquiera en los supuestos de juez único». P. Moneta, Prolusione del Prof. Avv. Rot. Paolo Moneta al Tribunale Ecclesiastico Regionale Umbro, en http://www.tribunaleecclesiasticoumbro.it/index. php?option $=$ com_content $\&$ view $=$ article $\&$ id $=136$ :prolusione-profpaolo-moneta $\&$ catid $=39$ :diesannualis\&Itemid $=123$, p. 6 , había propuesto generalizar la posibilidad de tramitar las causas de nulidad ante un único juez, aunque también anotaba que la decisión mediante un colegio garantiza mejor la objetividad y la tranquilidad de conciencia de los jueces. Proponía que si se decidía la tramitación ante un juez único, éste fuera el Obispo. 
aunque sea menos llamativa que otras, puede resultar de importancia para nombrar en el futuro jueces bien preparados ${ }^{21}, \mathrm{y}$ ha sido considerada como una de las medidas más eficaces en orden a dar agilidad y celeridad a los procesos ${ }^{22}$. No obstante, «incluso en las diócesis más pequeñas, el tribunal diocesano debe tener al menos un juez clérigo, un defensor del vínculo y un notario» ${ }^{23}$.

La responsabilidad del Obispo se ha visto reforzada en la reforma ${ }^{24}$, al atribuírsele la competencia de nombrar hasta dos jueces laicos para que formen parte del tribunal colegiado. Asimismo, es competencia del Obispo Diocesano, encomendar a un juez único (que ha de ser sacerdote), si no resulta posible constituir un tribunal colegiado, la tramitación de la casusa de nulidad. El ejercicio de ambas competencias es exclusivo del Obispo ${ }^{25}$, sin necesidad de que intervenga la Conferencia Episcopal ${ }^{26}$. Ahora bien, la responsabilidad del

${ }^{21}$ P. Moneta, Prolusione del Prof. Avv. Rot. Paolo Moneta al Tribunale Ecclesiastico Regionale Umbro..., 7 , señala que un buen juez puede, con normas procesales inadecuadas, llevar a cabo un buen juicio; en cambio, un mal juez, aunque disponga de normas procesales excelentes, difícilmente conducirá un buen juicio.

22 C. Morán Bustos, Retos de la reforma procesal de la nulidad del matrimonio, Ius Canonicum 56 (2016) 25, en su opinión esta norma contribuirá a facilitar la configuración de los turnos. El tratamiento podría ser aún más ágil si los laicos pudieran ser presidentes del turno (p. 26). Si pueden ser mayoría en el colegio, no se entiende por qué no pueden presidirlo (p. 26). Sobre la participación de los laicos con carácter general, vid:: A. VIANA, El problema de la participación de los laicos en la potestad de régimen. Dos vías de solución, Ius Canonicum 54 (2014) 603 y ss. M. E. OLMOS ORTEGA, Laicos y oficios eclesiásticos, Revista Española de Derecho Canónico 58 (2001) 557575. M. E. Olmos OrTega, La participación de laicos en los órganos de gobierno de la Iglesia (con especial referencia a la mujer), Revista Española de Derecho Canónico 46 (1989) 105 y ss. hace especial referencia a la participación en la esfera judicial.

23 Conferenza Episcopale Italiana, Segretaría generale. Texto fruto del Tavolo di lavoro, 20-VII2016. Acesible en http://bibliotecanonica.net/docsap/btcapz.pdf. Consulta del día 28-I-2017.

${ }^{24}$ Como se suele hacer notar al comentar el MI, el Derecho en este caso va unido a la pastoral, cfr. Amoris Laetitia, n. 244: «hacer evidente que el mismo Obispo en su Iglesia, de la que es constituido pastor y cabeza, es por eso mismo juez entre los fieles que se le han confiado». Por ello, «la aplicación de estos documentos es una gran responsabilidad para los Ordinarios diocesanos, llamados a juzgar ellos mismos algunas causas y a garantizar, en todos los modos, un acceso más fácil de los fieles a la justicia. Esto implica la preparación de un número suficiente de personal, integrado por clérigos y laicos, que se dedique de modo prioritario a este servicio eclesial. Por lo tanto, será, necesario poner a disposición de las personas separadas o de las parejas en crisis un servicio de información, consejo y mediación, vinculado a la pastoral familiar, que también podrá acoger a las personas en vista de la investigación preliminar del proceso matrimonial (cfr. Mitis Iudex Dominus Iesus, arts. 2-3)».

25 Subsidio aplicativo, 10: «el juez único es constituido por el obispo. El proceso judicial requiere, si es posible, el juez colegial, pero es potestad del Obispo, nombrar un juez único, siempre clérigo, en primera instancia, en forma estable o en los casos singulares. El Obispo deberá vigilar de todas maneras que no se incurra en ninguna forma de laxitud».

26 C. PeÑa García, Agilización de los procesos canónicos de nulidad matrimonial..., 52. 
Obispo no se agota en la misión de juzgar, sino que se extiende también a su deber de procurar una mayor colaboración del tribunal con las estructuras diocesanas de pastoral familiar ${ }^{27}$. Esta colaboración reviste una especial importancia por lo que se refiere a la investigación prejudicial ${ }^{28}$.

Autorizadas opiniones doctrinales han manifestado que no ven «razones fundadas para no haber abierto la posibilidad de juez único también en segunda instancia ${ }^{29} \mathrm{o}$ de jueces únicos que sean laicos ${ }^{30}$, o de que los laicos pudieran presidir un tribunal colegiado. Todas estas medidas habrían eliminado eventuales obstáculos para el ejercicio ágil y competente de la función judicial, donde no haya sacerdotes suficientes, pero cuenten con laicos preparados.

\section{El Mismo Obispo es JUEZ}

La característica más destacada de la reforma tal vez sea que subraya la posición del Obispo como juez de la diócesis ${ }^{31}$, encomendándole la obligación de juzgar personalmente algunas causas de nulidad. Éste es un cambio importante no sólo respecto a la tramitación de las nulidades matrimoniales, sino respecto al criterio hasta ahora establecido en el código de descentralizar la actividad judicial. En el Subsidio aplicativo, se recuerda: «El Obispo en su Iglesia, como padre y juez, es icono de Cristo-Sacramento. Por lo tanto, él sea

${ }^{27}$ C. PeÑa García, Agilización de los procesos canónicos de nulidad matrimonial..., 53. C. PeÑa GaRCÍA, El nuevo proceso «breviore coram episcopo» para la declaración de la nulidad matrimonial, Monitor Ecclesiasticus 130 (2015) 571, «el Derecho canónico no se opone a caridad y misericordia o a pastoral, sino a arbitrariedad a inseguridad jurídica y a injusticia».

${ }^{28}$ P. A. Moreno García, El servicio de indagación prejudicial: aspectos jurídico-pastorales, Ius Canonicum 56 (2016) 65-85. M. J. ARROBA CONDE, La pastoral judicial y la preparación de la causa en el Motu Proprio Mitis Iudex Dominus Iesus, en M. E. Olmos Ortega (ed.), Procesos de nulidad matrimonial. Tras la reforma del Papa Francisco, Madrid 2016, 63-82. F. J. REgordán BARBERO, La investigación preliminar en las nuevas normas procesales del M. P. 'Mitis Iudex Dominus Iesus', Anuario de Derecho Canónico supl. 5 (2016) 39 y ss.

29 C. Morán Bustos, Retos de la reforma procesal..., 26.

30 C. Morán Bustos, Retos de la reforma procesal..., 26. Ya antes de la reforma J. LLOBELL, Los procesos matrimoniales en la Iglesia, Madrid 2014, 127-128.

31 En este sentido se expresa la Relatio Synodii: «Acerca de las causas matrimoniales, la agilización del procedimiento -requerido por muchos- además de la preparación de suficientes agentes, clérigos y laicos con dedicación prioritaria, exige resaltar la responsabilidad del Obispo diocesano, quien en su diócesis podría encargar a consultores debidamente preparados que aconsejaran gratuitamente a las partes acerca de la validez de su matrimonio. Dicha función puede ser desempeñada por una oficina o por personas cualificadas (cfr. Dignitas Connubii, art. 113, 1)» Relatio Synodii, n. 49, en http://www.vatican.va/roman_curia/synod/documents/rc_synod_doc_20141018_ relatio-synodi-familia_sp.html. 
personalmente juez, dando un signo de la potestad sacramental. Esto vale especialmente para el proceso más breve: no es el Obispo quien instruye la causa, interrogando a las partes y testigos, sino que él interviene como juez en los casos en los que es evidente la nulidad. La verdad del juicio es garantizada, ya que personas cualificadas asisten al Obispo, el cual asume luego la certeza moral sobre la sentencia a pronunciar» ${ }^{32}$.

En el proceso documental ${ }^{33}$, la única novedad es que el juez que dicta sentencia puede ser el mismo Obispo diocesano ${ }^{34}$. En el proceso abreviado, el Obispo debe ejercer personalmente la función judicial, no cabe la posibilidad de delegar la decisión ${ }^{35}$.

Los aspectos antes mencionados dentro de este criterio resultan claros. Hay otros aspectos cuya aplicación ha suscitado más dificultades. Así, el Pontificio Consejo para los Textos Legislativos contesta a una diócesis italiana que manifestaba sus dudas respecto al modo de proceder, debido a la existencia en Italia de los Tribunales Regionales, que para poder acoger en cada Diócesis el procedimiento breve de nulidad regulado en los cc. 1683-1687, no es necesario instituir un tribunal propio en cada diócesis, pues es el Obispo diocesano el «juez monocrático» competente para esas causas. El Obispo diocesano deberá servirse de dos oficios para poder juzgar: del Vicario judicial, cuyo nombramiento estable es preceptivo a tenor del c. $1420 \$ 1$ CIC que es a quien corresponde aceptar el libelo de demanda que introduce la causa (arts. 15 y 16 de las normas procedimentales) y el defensor del vínculo (cc. 1435-1436), que necesariamente deberá actuar en el proceso. Asimismo, el Obispo diocesano deberá disponer de los instructores y asesores a los que se refiere el nuevo canon 1685. Estos oficios no es necesario que sean establemente instituidos, pueden nombrarse ad casum. Así pues, en Italia, los Obispos diocesanos podrán seguir enviando al Tribunal regional las causas que deban tramitarse por el procedimiento contencioso ordinario de nulidad, y deberán, en cambio, deci-

32 Subsidio aplicativo, 9-10.

33 S. Panizo Orallo, Proceso documental, en J. Otaduy - A. Viana - J. Sedano (dirs.), Diccionario General de Derecho Canónico, vol. VI, Cizur Menor (Navarra) 2012, 515-520.

34 C. Morán Bustos, Retos de la reforma procesal..., 27. El actual can. 1688 establece: «Una vez recibida la petición hecha conforme al c. 1676, el Obispo diocesano, o el Vicario judicial o el juez designado, puede declarar mediante sentencia la nulidad de un matrimonio, omitiendo las solemnidades del proceso ordinario, pero citando a las partes y con intervención del defensor del vínculo, si por un documento al que no pueda oponerse ninguna objeción ni excepción consta con certeza la existencia de un impedimento dirimente o el defecto de forma legítima, con tal de que conste con igual certeza que no se concedió dispensa, o que el procurador carece de mandato válido».

35 C. PEÑa García, Agilización de los procesos canónicos de nulidad matrimonial..., 51. 
dir personalmente las que se tramiten por el procedimiento breve. Desde el punto de vista de los cónyuges que deseen solicitar la nulidad de su matrimonio, pueden dirigirse tanto al Vicario Judicial de su diócesis, si se cumplen las condiciones para que la causa pueda tramitarse por el procedimiento breve ante el Obispo, como al Presidente del Tribunal regional en la que su diócesis esté integrada, si la causa es más compleja o falta el consentimiento del demandado (nuevo c. $1683,1^{\circ}$ CIC). En todo caso, el Vicario Judicial y el Presidente del Tribunal regional deberán proceder conforme a lo previsto en el art. 15 de las reglas procedimentales ${ }^{36}$.

Esta interpretación es distinta de la que expresó el Decano de la Rota Romana en L'Osservatore Romano. El 4 de noviembre, en el Palacio de la Cancillería, se celebró el acto de apertura del nuevo año académico del Estudio rotal. Tres días después, L'Osservatore Romano refiere que al iniciar la ceremonia el Decano de la Rota Romana, monseñor Pío Vito Pinto -ex presidente de la comisión de redacción del motu proprio-, leyó la siguiente declaración: «El Santo Padre, con la finalidad de aportar una claridad definitiva en la aplicación de los documentos pontificios sobre la reforma matrimonial, ha pedido al Decano de la Rota Romana que se manifieste claramente la intención del supremo legislador de la Iglesia sobre los dos motu proprio promulgados el 8 de septiembre del 2015:

$\gg 1$. El Obispo diocesano tiene el derecho nativo y libre a causa de esta ley pontificia de ejercer personalmente la función de juez y de erigir su tribunal diocesano;

2. En el interior de la provincia eclesiástica, los obispos pueden decidir libremente crear un tribunal interdiocesano, en el caso de que no reconozcan la posibilidad en el futuro inmediato de constituir su propio tribunal; manteniendo, en conformidad con el derecho y con licencia de la Santa Sede, la capacidad que metropolitanos de dos o más provincias eclesiásticas puedan ponerse de acuerdo en crear el tribunal interdiocesano tanto de primera como de segunda instancia».

Un mes después, el Romano Pontífice Francisco, mediante el rescripto ex audientia entregado el 7 de diciembre al Decano de la Rota Romana y hecho público el 11 de diciembre, declara: «Las leyes de reforma del proceso matrimonial suscitadas abrogan o derogan toda ley o norma contraria hasta

${ }^{36}$ Respuesta del 18-XI-2015, Prot. N. 15201/2015. Original en italiano. 
ahora vigente -general, particular o especial- también eventualmente aprobada en forma específica (como, por ejemplo, el motu proprio "Qua cura", dado por mi antecesor Pío XI en tiempos muy distintos a los presentes)».

En suma, después del rescripto de 7-XII-2015 ha quedado clara la posibilidad de que los Obispos italianos erijan sus propios tribunales, sin necesidad de obtener dispensa alguna de la Santa Sede, previa solicitud al Tribunal de la Signatura Apostólica. De la interpretación orientativa del Pontificio Consejo sobre este punto, sigue resultando de interés la orientación a los fieles de dirigirse al Vicario Judicial de su diócesis o al presidente del tribunal regional, mientras que su Obispo no haya erigido un tribunal diocesano o haya dispuesto unirse con otra diócesis, como permite el nuevo c. 1673:

$\$ 1$. «En cada diócesis el juez de primera instancia para las causas de nulidad del matrimonio, para las cuales el derecho no haga expresamente excepción, es el Obispo diocesano, que puede ejercer la potestad judicial por sí mismo o por medio de otros, conforme al derecho.

$\$ 2$. El Obispo constituya para su diócesis el tribunal diocesano para las causas de nulidad de matrimonio, quedando a salvo la facultad para el mismo Obispo de acceder a otro tribunal cercano, diocesano o interdiocesano».

La centralidad del obispo en el ejercicio de la potestad judicial se manifiesta en la creación del proceso breve, en el que él mismo actúa como juez, y en el derecho y el deber de erigir un tribunal diocesano y en la posibilidad (si bien no obligación, como en el proceso breve) de que la sentencia en el proceso documental la dicte el Obispo personalmente. Ahora bien, la solución de los problemas que se han detectado en los procesos de nulidad, no parece que se resuelva sólo con encargarle al Obispo los asuntos judiciales ${ }^{37}$. Cuesta imaginar que arzobispos de grandes Diócesis puedan dedicar tiempo suficiente a

37 S. BuENo SALINAS, La reforma de los procesos canónicos de declaración de nulidad de matrimonio. La celeridad del proceso..., 17, «si el obispo no es jurista ni tiene experiencia canónica, el problema no se solucionará simplemente por encargarle a él los asuntos judiciales, y confiar en que podrá decidir con la ayuda de dos laicos sensatos (por tanto, no juristas) es más bien admitir la precariedad de la situación, pero no optar por una solución que ofrezca reales garantías en justicia». C. PeÑa GaRCía, El nuevo proceso «breviore coram episcopo» para la declaración de la nulidad matrimonial..., 570, nota 6, «La revalorización del papel del Obispo en las causas de nulidad no se cumple preferentemente por la reserva de algunas causas al Obispo -que será siempre necesariamente algo minoritario- sino que pasa por tomar conciencia de la responsabilidad de éste en los "oficios implicados" seleccionando personas técnicamente preparadas». 
la decisión de los procesos matrimoniales breves, y ni siquiera parece lo más conveniente si se desea ganar en celeridad ${ }^{38}$.

\section{EL PROCESO MÁS BREVE}

El nuevo c. 1676 establece:

$\$ 1$. «Recibida la demanda, el Vicario judicial, si considera que ésta goza de algún fundamento, la admita y, con decreto adjunto al pie de la misma demanda, ordene que una copia sea notificada al defensor del vínculo y, si la demanda no ha sido firmada por ambas partes, a la parte demandada, dándole el término de quince días para expresar su posición respecto a la demanda.

$\$ 2$. Transcurrido el plazo predicho, después de haber amonestado nuevamente a la otra parte, si lo ve oportuno y en la medida que así lo estime, para que manifieste su posición, oído el defensor del vínculo, el Vicario judicial con un decreto suyo determine la fórmula de dudas y establezca si la causa debe tratarse con el proceso más breve conforme a los cánones 1683-1687. Este decreto debe ser notificado enseguida a las partes y al defensor del vínculo.

$\$ 3$. Si la causa debe ser tratada con el proceso ordinario, el Vicario judicial, con el mismo decreto, disponga la constitución del colegio de jueces o del juez único con los dos asesores según el can. $1673 \$ 4$.

$\$ 4$. Si en cambio se dispone el proceso más breve, el Vicario judicial proceda conforme al can. 1685.

$\$ 5$. La fórmula de la duda debe determinar por qué capítulo o capítulos se impugna la validez de las nupcias».

La reforma ha querido la preeminencia del proceso breve ante el Obispo $^{39}$, y esa preeminencia - que ha sido calificada como una reforma histórica ${ }^{40}-$ no debe ser desobedecida ${ }^{41}$. La doctrina ha calificado a este proceso como ju-

${ }^{38}$ S. Bueno Salinas, La reforma de los procesos canónicos de declaración de nulidad de matrimonio. La celeridad del proceso..., 17.

39 G. BoNI, La recente riforma del proceso di nullità matrimoniale. Problemi, criticità, dubbi (parte seconda), Stato Chiese e pluralismo confessionale 10 (2016) 2, www.statochiese.it.

40 O. DE BerTolis, Papa Francesco riforma il processo canonico matrimoniale, Quaderno 3967 del 10X-2015 (Civ. Catt. IV 3-102), 59-68.

${ }^{41}$ M. DEL Pozzo, L'organizzazione giudiziaria ecclesiastica alla luce del m. p. Mitis Iudex, Stato Chiese e pluralismo confessionale (novembre 2015) 9, www.statochiese.it. 
dicial, sumario y extraordinario ${ }^{42}$ o especial ${ }^{43}$, recomendando que $\ll$ la opción por el proceso brevior debería ser una opción extraordinaria y excepcional, y debería venir justificada, no por la agilidad y la celeridad, sino por la evidencia de la nulidad (y el resto de los requisitos del can. 1683)» ${ }^{44}$.

La novedad quizá más importante de la reforma es este nuevo procedimiento abreviado ante el Obispo ${ }^{45}$. La resolución del proceso breve (no la entera tramitación), se encomienda al Obispo ${ }^{46}$. Al establecerse como obligación del Obispo decidir personalmente algunas causas de nulidad matrimonial, se modifica lo previsto en el CIC respecto a la obligación de no ejercer la función judicial personalmente ${ }^{47}$. Más aún, este tipo de juicios breves, se reservan exclusivamente al Obispo diocesano, sin que quepa que actúe el Obispo auxiliar, por recusación ${ }^{48} \mathrm{o}$ inhibición del Obispo diocesano ${ }^{49}$. El texto de la norma se refiere con claridad al Obispo diocesano, y así ha quedado reafirmado en el Subsidio aplicativo: «corresponde al Obispo diocesano pronunciar la sentencia y esta competencia exclusiva no puede ser delegada a un tribunal diocesano o interdiocesano por las siguientes razones: a) por una razón de orden teológico-jurídico que subyace a la reforma (se requiere que el Obispo personalmente sea signo de la cercanía de la justicia eclesiástica a los fieles y garante contra posibles abusos); b) por una razón de orden sistemático, porque el examen de la eventual apelación se ha de remitir al metropolita o al Decano de la Rota Romana, y ello no sería posible si la sentencia fuera emitida por un tribunal colegial» ${ }^{50}$.

${ }^{42}$ C. PeÑa García, Agilización de los procesos canónicos de nulidad matrimonial..., 55.

43 C. PeÑa GARCÍA, El nuevo proceso «breviore coram episcopo»..., 589-590, lo califica de «sumario y especial». M. J. ARROBa CONDE, El proceso más breve ante el Obispo, en L. RUANo EsPINA - C. GUZMÁN PÉREZ (eds.), Reforma de los procesos de nulidad y otras novedades legislativas de Derecho canónico y eclesiástico del Estado, Madrid 2017, 253-254, destaca su carácter judicial y extraordinario.

44 C. Morán Bustos, Retos de la reforma procesal..., 28.

${ }^{45}$ M. DEL Pozzo, La organizzazione giudiziaria ecclesiastica alla luce del m. p. «Mitis iudex»..., 9. Al Obispo diocesano se equiparan quienes presiden las circunscripciones equiparadas a las diócesis: la prelatura territorial, la abadía territorial, el vicariato apostólico, la prefectura apostólica y la administración apostólica establemente erigida, cfr. cc. $134 \$ 3,368,381 \$ 2$.

46 C. PeÑa García, Agilización de los procesos canónicos de nulidad matrimonial..., 55.

${ }^{47}$ M. DEL Pozzo, La organizzazione giudiziaria ecclesiastica alla luce del m. p. «Mitis iudex»..., 8.

${ }^{48}$ El supuesto de recusación de un juez por motivo de consanguinidad (cc. 1448 y 1449 \$ 1) puede suscitarse también cuando el Obispo sea juez.

49 G. NúÑ̃Z, El proceso brevior: exigencias y estructura, Ius Canonicum 56 (2016) 139, nota 13. G. BONI, La recente riforma del proceso di nullità matrimoniale. Problemi, criticità, dubbi (parte prima)..., 70-71.

${ }^{50}$ Subsidio aplicativo, 41. 
La razón de esta reserva es garantizar la indisolubilidad, según consta en el preámbulo, VI, párrafo $2^{\circ}$ en palabras del Sumo Pontífice: «no se me escapa, sin embargo, cuánto un juicio abreviado pueda poner en riesgo el principio de la indisolubilidad del matrimonio; precisamente por esto he querido que en tal proceso sea constituido juez el mismo Obispo, que en virtud de su oficio pastoral es con Pedro el mayor garante de la unidad católica en la fe y la disciplina».

Para que una causa pueda tramitarse por el procedimiento abreviado, es necesario que se cumplan los siguientes requisitos ${ }^{51}$ :

El primer requisito es que ambas partes estén de acuerdo en solicitar la nulidad (Ratio procedendi, 4): El litisconsorcio activo -inicial o sobrevenido- es el primero de los requisitos establecidos por el c. 1683. Como se ha señalado por la doctrina, «el acuerdo no sólo debe versar sobre el hecho de que el matrimonio sea declarado nulo, sino también sobre el motivo o capítulo de nulidad (designados con el mismo nomen iuris), de lo contrario no existiría un verdadero litisconsorcio ${ }^{52}$.

El segundo requisito es que se trate de un supuesto de nulidad evidente, que a tenor del art. art. $14 \$ 1$ de la Ratio procedendi, son los siguientes:

«Entre las circunstancias que pueden permitir tratar la causa de nulidad del matrimonio a través del proceso más breve según los cánones 16831687 , se cuentan por ejemplo: la falta de fe que puede generar la simulación del consentimiento o el error que determina la voluntad, la brevedad de la convivencia conyugal, el aborto procurado para impedir la procreación, la obstinada permanencia en una relación extra conyugal al momento de las nupcias o en un tiempo inmediatamente sucesivo, la ocultación dolosa de la esterilidad o de una grave enfermedad contagiosa o de hijos nacidos en una relación precedente o de un encarcelamiento, un motivo para casarse totalmente extraño a la vida conyugal o consistente en el embarazo imprevisto de la mujer, la violencia física ejercida para arrancar el consentimiento, la falta de uso de razón comprobada por documentos médicos, etc.».

Este precepto no establece nuevas causas de nulidad, sino que enumera a título ejemplificativo, circunstancias $^{53}$ que permiten la tramitación de la causa

${ }^{51}$ F. Heredia Esteban, El proceso más breve ante el Obispo, Anuario de Derecho Canónico supl. 5 (2016) 105-111.

${ }_{52}^{53}$ P. A. Moreno García, El servicio de indagación prejudicial: aspectos jurídico-pastorales..., 69.

${ }^{53}$ M. AlENDa SALINAS, ¿Nuevas causas de nulidad matrimonial canónica? El sentido del art. 14 \$ 1 de las reglas de procedimiento contenidas en la Carta Apostólica Mitis Iudex Dominus Iesus, Revista Ge- 
a través del nuevo proceso abreviado ante el Obispo. Merece destacarse de esta enumeración que casi todas las circunstancias aluden a vicios del consentimiento. Éstas no pueden tramitarse por el proceso documental sumario ${ }^{54}$, (regulado ahora en los cc. 1688-1690) y, por ello, serán las causas de matrimonios viciados las que probablemente se tramiten por el nuevo procedimiento ante el Obispo ${ }^{55}$. El tenor del precepto, «la falta de fe que puede generar la simulación del consentimiento o el error que determina la voluntad», reafirma la doctrina tradicional según la cual la validez del matrimonio no requiere la fe de los contrayentes, sino la voluntad matrimonial, expresada a través del consentimiento naturalmente suficiente. A la vez, supone una toma en consideración de la falta de fe subjetiva, como elemento que puede ser causa de simulación o de error que determine la voluntad ${ }^{56}$.

En opinión de buena parte de la doctrina, si se aplica correctamente la normativa del motu proprio, estos procesos no pueden ser habituales, pues es difícil que se dé un litisconsorcio (inicial o sobrevenido), y que en el momento de la presentación ya se cuente con las pruebas oportunas e indiscutibles; la mayor parte de los procesos invocan el c. 1095, 2 y 3, y en éstos es muy raro que el caso sea evidente desde el inicio. Sin embargo, ello no significa que las causas por estos capita nullitatis no puedan tramitarse por el proceso breve ante el Obispo. Según los medios de comunicación, hay algún tribunal que está tramitando casi todas las demandas por el proceso breve según. Al no tener que acudir a segunda instancia, si en algún caso se ha producido una irregularidad procesal, corresponderá al Tribunal de la Signatura apostólica corregir esas

neral de Derecho Canónico y Eclesiástico del Estado 40 (2016). M. D. Cebriá García, Las circunstancias y hechos orientativos de la nulidad clara del art. 14 del Motu Proprio Mitis Iudex Dominus Iesus, para abrir el proceso breve ante el Obispo, Revista General de Derecho Canónico y Eclesiástico del Estado 40 (2016). J. FERRER ORTIZ, Valoración de las circunstancias que pueden dar lugar al proceso abreviado, Ius Canonicum 56 (2016) 157-192.

${ }^{54}$ C. PeÑa GarCía, El nuevo proceso «breviore coram episcopo»..., 591-592, propone ampliar el alcance del proceso documental a los casos de vicios del consentimiento en los que haya documentos irrefutables (pericias médicas o psicológicas), ello ampliaría la posibilidad de tramitar las causas por incapacidad consensual sin el consentimiento de una de las partes.

${ }^{55}$ C. Morán Bustos, El proceso «brevior» ante el obispo, M. E. Olmos Ortega (ed.), Procesos de nulidad matrimonial. Tras la reforma del Papa Francisco, Madrid 2016, 150, afirma que el principio general de la pericia pública o de oficio en los supuestos de impotencia y de incapacidad consensual (c. 1095), ratificado en el actual c. 1678, 3, significa, a juicio de Morán, que no se podrá seguir el proceso breve en esos supuestos pues no hay pericia pública o de oficio.

${ }^{56}$ A. P. TAVANI, Fede e consenso matrimoniale, Torino 2013. M. Á. ORTIZ, Fe y matrimonio, en J. BosCH (ed.), Cuestiones actuales Derecho canónico y Derecho eclesiástico del Estado, Dykinson, Madrid 2015, 267 y ss. 
prácticas $^{57}$. A tenor de la Constitución Pastor Bonus, art. 121, este dicasterio (Tribunal de la Signatura Apostólica), «además de ejercer la función de Tribunal Supremo, provee a la recta administración de la justicia en la Iglesia». Asimismo el art. 124 declara que «Al mismo le corresponde también. $1^{\circ}$ vigilar sobre la recta administración de la justicia (...)».

En todo caso, como consta en el Subsidio aplicativo, «el Obispo puede sólo emitir sentencia afirmativa, si adquiere la certeza moral requerida. De otro modo remite la causa al proceso ordinario» ${ }^{58}$.

La técnica jurídica de este nuevo proceso ante el Obispo, tiene algunos defectos que reflejan (o al menos eso parece) que ha sido elaborado con prisa. De hecho, hay aspectos casi inaplicables (por ejemplo, la rapidez en la litiscontestatio que exige el $\mathrm{mp}$, pues entra en conflicto con la seguridad en la notificación a la parte demandada y con el derecho de defensa). Otros parecen contradictorios como la constitución del tribunal después de la litiscontestatio, al mismo tiempo que, si se rechaza la demanda, cabe recurso ante el tribunal colegiado, todavía no constituido.

\section{LA APELACIÓN A LA SEDE METROPOLITANA}

En el Proemio del MI se hace constar: «Conviene que se restaure la apelación a la Sede del Metropolitano, ya que este oficio de cabeza de la provincia eclesiástica, estable en los siglos, es un signo distintivo de la sinodalidad de la Iglesia». En conformidad con este criterio, el nuevo c. $1687 \$ 3$, establece: «Contra la sentencia del Obispo se da apelación al Metropolitano o a la Rota Romana; si la sentencia fue dada por el Metropolitano, se da apelación al sufragáneo más antiguo; y contra la sentencia de otro Obispo que no tiene otra autoridad superior debajo del Romano Pontífice, se da apelación al Obispo por él designado establemente. $\$ 4$. Si resulta evidente que la apelación es meramente dilatoria, el Metropolitano o el Obispo mencionado en el $\$ 3$, o el Decano de la Rota Romana, la rechazará por decreto desde el primer momento; si en cambio se admite la apelación, se envíe la causa al examen ordinario en el segundo grado».

\footnotetext{
${ }^{57}$ Sobre las competencias de la Signatura Apostólica, K. MARTENS, Signatura Apostólica Tribunal de la, en J. Otaduy - A. Viana - J. Sedano (dirs.), Diccionario General de Derecho Canónico, vol. VII, Cizur Menor (Navarra), 2012, 311-312.

${ }^{58}$ Subsidio aplicativo, 41. C. MORÁn Bustos, Retos de la reforma procesal..., 28.
} 
En Italia, la apelación a la Sede metropolitana ha dado origen a dudas interpretativas, que inicialmente fueron resueltas por el Pontificio Consejo para los textos legislativos en un sentido ${ }^{59}$, y que a partir del documento fruto del trabajo de la Comisión erigida por el Santo Padre, el 1 de junio de 2016, y coordinada por el Secretario General de la Conferencia Episcopal Italiana, ha tenido finalmente una solución distinta. El Pontificio Consejo entendió que la antigüedad a la que hace referencia el canon mencionado es la de la consagración episcopal, mientras que el documento de trabajo conjunto de la Conferencia Episcopal italiana, el Decano de la Rota y el Presidente del Pontificio Consejo ha considerado que la antigüedad a la que se refiere es la del cargo.

Además de la apelación a la sede metropolitana, en la aplicación del MI, se suscitan otras cuestiones relativas al metropolitano, con ocasión de la constitución de tribunales. Para resolverlas, el Subsidio aplicativo contiene prescripciones de algún modo innovadoras respecto del $\mathrm{MI}^{60}$. Así, por ejemplo, la reserva al Arzobispo metropolitano de la firma de la solicitud al Prefecto del Supremo Tribunal de la signatura apostólica a fin de obtener licencia para constituir el tribunal interdiocesano de primera y segunda instancia ${ }^{61}$. Esta circunstancia, suscita lógicamente la cuestión siguiente: El Subsidio aplicativo, ¿qué valor jurídico tiene? O dicho de otro modo, ¿cuál es su naturaleza jurídica ${ }^{62}$ ? Ha sido publicado en italiano en el diario Avvenire, el 4 de febrero de 2016, figurando como autor el Tribunal Apostólico de la Rota Romana ${ }^{63}$. Hasta donde conocemos, nadie le atribuye valor normativo ${ }^{64}$, sin embargo contiene innovaciones como la restricción del derecho a pedir un cambio al metropolitano.

\footnotetext{
${ }^{59}$ Según Mons. Arrieta, la naturaleza de esas notas aclaratorias del Pontificio consejo para los textos legislativos es orientativa. No son interpretaciones auténticas. R. SERRES LóPEZ DE GUERENU, El motu proprio «Mitis Iudex Dominus Iesus»: un servicio de misericordia y de verdad, Ius Communionis 4 (2016) 73, afirma que las respuestas particulares dadas por el PCTL no tienen valor normativo, sino que manifiestan la posición doctrinal de este dicasterio.

${ }^{60}$ R. SERres LóPEZ de GuereÑu, El motu proprio «Mitis Iudex Dominus Iesus»..., 72-73, afirma refiriéndose a la mens del Pontífice y al rescripto que ambos tienen valor de ley, porque han sido dados por la autoridad del Papa para interpretar auténticamente el motu proprio, en cambio, del Subsidio aplicativo afirma que no tiene por sí mismo valor jurídico, sino un gran valor orientativo.

${ }^{61}$ G. BONI, La recente riforma del proceso di nullità matrimoniale. Problemi, criticità, dubbi (parte pri$m a) \ldots, 49$.

${ }^{62}$ G. NúNEZE, El proceso brevior: exigencias y estructura, Ius Canonicum 56 (2016) 136.

${ }^{63} \mathrm{G}$. BonI, La recente riforma del proceso di nullità matrimoniale. Problemi, criticità, dubbi (parte prima)..., 47.

${ }^{64}$ R. SeRres López de Guereñu, El motu proprio «Mitis Iudex Dominus Iesus»..., 73, le atribuye valor didáctico. J. Llobell, Cuestiones acerca de la apelación y la cosa juzgada..., 60, nota 17, habla de que «la naturaleza "subsidiaria" de este documento resulta notablemente potenciada por su traducción a diversos idiomas».
} 
La constitución de tribunales interdiocesanos dentro de la misma sede metropolitana es libre con comunicación a la Signatura Apostólica ${ }^{65}$. En cambio, la constitución de tribunales interdiocesanos constituidos entre diócesis pertenecientes a sedes metropolitanas o provincias eclesiásticas diferentes, requiere la licencia de la Signatura apostólica ${ }^{66}$. Da la impresión de que los antiguos tribunales regionales o interdiocesanos ${ }^{67}$ que existían sobre todo en Italia, pueden seguir existiendo, si los Obispos diocesanos así lo desean (y la Signatura Apostólica los autoriza). Sin embargo, tanto por la centralidad del Obispo diocesano en la reforma como por la novedad del recurso a la sede metropolitana, probablemente se vayan disolviendo los tribunales interdiocesanos hasta ahora existentes. En España hay sólo dos: el de Aragón ${ }^{68}$-que hasta donde conozco no se ha disuelto- y el Hispalense. En este segundo supuesto, han constituido un tribunal diocesano propio y han dejado de estar integrados en el interdiocesano, las Diócesis de Córdoba ${ }^{69}$, Cádiz ${ }^{70}$ y Asidonia-Jerez ${ }^{71}$ y Huelva ${ }^{72}$.

En Alemania ${ }^{73}$, la Diócesis de Essen designó como tribunal diocesano al de la archidiócesis de Colonia y las Diócesis han constituido un tribunal inter-

${ }^{65}$ Conferenza episcopale Italiana, Segretaría generale. Texto fruto del Tavolo di lavoro, 20-VII-2016.

${ }^{66}$ Conferenza episcopale Italiana, Segretaría generale. Texto fruto del Tavolo di lavoro, 20-VII-2016.

${ }^{67}$ M. A. Hack, Tribunal interdiocesano, en J. OTAdUy - A. Viana - J. Sedano (dirs.), Diccionario General de Derecho Canónico, vol. VII, Cizur Menor (Navarra) 2012, 674, los términos tribunal interdiocesano y tribunal regional son sinónimos.

${ }^{68} \mathrm{El}$ pasado viernes 23 de junio 2006 se celebró Zaragoza el 25 aniversario del tribunal interdiocesano de Aragón. Estuvieron presentes los Obispos de las diócesis aragonesas y D. Elías Yanes, arzobispo emérito de Zaragoza y principal impulsor de estos tribunales. También asistieron los vicarios judiciales de las diócesis aragonesas y un numeroso grupo de abogados, que trabajan en los procesos de nulidad. http://www.diocesisdehuesca.org/informacion/articulosyentrevistas/20052006/Entrevista.htm.

${ }^{69}$ El 14 de julio de 2014, el Sr. Obispo de Córdoba, D. Demetrio Fernández González, después de consultar al Consejo Episcopal y al Vicario Judicial y Presidente de la Sección Diocesana de Córdoba del Tribunal interdiocesano de Primera Instancia de Sevilla, llegó al convencimiento que era mejor para nuestra Diócesis de Córdoba independizarnos del Tribunal interdiocesano, al que pertenecemos desde 1982, y funcionar autónomos como Tribunal diocesano. Esta decisión fue comunicada al Arzobispo de Sevilla, Presidente del Tribunal interdiocesano de Primera Instancia de Sevilla, y a la Signatura Apostólica. El 4 de septiembre de 2015, dicho Tribunal Supremo, mediante decreto, ratificó la decisión tomada para que a partir del 1 de enero de 2016 el Tribunal diocesano de Córdoba comience su andadura de forma autónoma. Asimismo estableció como Tribunal de apelación el metropolitano de Madrid.

${ }^{70}$ Decreto de 1 de marzo de 2016, en http://www.obispadodecadizyceuta.org/sites/default/files/documentos/Decreto\%20Tribunal\%20Diocesano\%20Nulidad\%20Matrimonial.01-03-16.pdf.

${ }^{71}$ Decreto 13 de diciembre de 2015, en este Decreto consta que esta Diócesis sigue perteneciendo al tribunal interdiocesano por lo que se refiere a la segunda instancia.

${ }^{72}$ Decreto de 16 de febrero de 216, en http://www.diocesisdehuelva.es/index.php/curia/tribunal/.

${ }^{73}$ Para la consulta de los datos estadísticos de los Tribunales eclesiásticos de Alemania, puede verse la web del Arzobispado de Colonia. Aunque son muy completos, no se puede valorar aún el 
diocesano. El Tribunal eclesiástico de Osnabrück es tribunal interdiocesano para la diócesis de Osnabrück y para la Archidiócesis de Hamburgo. Desde su erección el 1 de julio de 1979, el tribunal interdiocesano de Erfurt, es competente para las causas de los obispados de Erfurt, Dresden-Meißen, Magdeburg y Görlitz, además de para la Exarquía Apostólica de los católicos Ucranianos de rito Bizantino en Alemania y en Escandinavia. Son tribunales de segunda instancia de este tribunal interdiocesano, el tribunal de archidiócesis de Berlín, para las causas provenientes de los obispados de Dresden-Meißen, Görlitz y el Tribunal de Paderborn para las causas provenientes de los obispados de Erfurt y Magdeburgo. No tenemos constancia de que haya intención de que dejen de existir estos tribunales interdiocesanos.

Hasta donde hemos podido comprobar, los tribunales interdiocesanos que comprenden un mayor número de fieles y un territorio más extenso son los de Iberoamérica. En Argentina, Buenos Aires ${ }^{74}$ y Córdoba ${ }^{75}$ y en México, la archidiócesis de México ${ }^{76}$.

En España, hay 70 diócesis, de las cuales 14 son archidiócesis, 55 dióce$\operatorname{sis}^{77}$, y 1 Arzobispado castrense ${ }^{78}$. Quizá, si en España se constituyera un gru-

impacto de la reforma procesal, pues son anteriores http://www.erzbistum-koeln.de/erzbistum/ offizialat/ueber_uns/statistisches/.

${ }^{74} \mathrm{El}$ Tribunal interdiocesano de Buenos Aires, extiende su jurisdicción sobre la arquidiócesis de Buenos Aires; las diócesis de Avellaneda-Lanús, Concordia, Gregorio de Laferrére, Gualeguaychú, Lomas de Zamora, Merlo-Moreno, Morón, San Isidro, San Justo, San Martín, San Miguel, San Nicolás de los Arroyos, Venado Tuerto y Zárate-Campana; las eparquías Armenia, Maronita y Ucrania; el obispado castrense y el Ordinariato Oriental.

${ }^{75} \mathrm{El}$ Tribunal interdiocesano de Córdoba, comprende la jurisdicción sobre las arquidiócesis de Córdoba, las diócesis de Cruz del Eje, San Francisco, Villa de la Concepción del Río Cuarto y Villa María; y la prelatura de Deán Funes.

${ }^{76}$ El Tribunal eclesiástico interdiocesano de México es Tribunal de Primera Instancia para la Arquidiócesis de México y las Diócesis de Atlacomulco, Cuernavaca, Toluca y Tenancingo y es también Tribunal de Segunda Instancia para las Arquidiócesis de México, Acapulco, Monterrey, Tlanepantla, Xalapa y Tulacingo, así como para las ya mencionadas Diócesis de Atlacomulco, Cuernavaca, Toluca y Tenancingo.

${ }^{77}$ Barcelona (Sant Feliú de Llobregat y Tarrasa), Burgos (Bilbao, Osma-Soria, Palencia y Vitoria) Granada (Almería, Cartagena, Guadix, Jaén y Málaga), Madrid (Alcalá de Henares y Getafe), Mérida-Badajoz (Coria-Cáceres, Plasencia), Oviedo (León, Santander, Astorga), Pamplona y Tudela (Calahorra y La Calzada-Logroño, Jaca, San Sebastián), Santiago de Compostela (Lugo, Mondoñedo-Ferrol, Orense, Tuy-Vigo), Sevilla (Asidonia-Jerez, Cádiz y Ceuta, Córdoba, Huelva, Canarias, San Cristóbal de La Laguna), Tarragona (Gerona, Lérida, Solsona, Tortosa, Urgel, Vich), Toledo (Albacete, Ciudad Real, Cuenca, Sigüenza-Guadalajara), Valencia (Ibiza, Mallorca, Menorca, Orihuela-Alicante, Segorbe-Castellón de la Plana), Valladolid (Ávila y Ciudad Rodrigo), Salamanca (Segovia y Zamora) y Zaragoza (Barbastro-Monzón, Huesca, Tarazona y Teruel-Albarracín).

${ }^{78}$ El Tribunal de la Rota de la Nunciatura es tribunal de primera, o ulterior instancia, del arzobispado castrense. 
po de trabajo similar al que se constituyó en junio de 2016 para la Conferencia Episcopal Italiana, habría que proponer, por ejemplo, que el Tribunal de la Nunciatura de la Rota de Madrid, fuera Tribunal de apelación de las Diócesis de Canarias, y no la Archidiócesis de Sevilla. Con ello, se facilitaría el acceso de los fieles a los Tribunales, y también se evitaría que la Archidiócesis Hispalense tenga la sobrecarga de causas que padece actualmente, y que suscitó que la Signatura Apostólica atribuyera a los Tribunales eclesiásticos dependientes de sede Metropolitana de la Archidiócesis de Toledo ${ }^{79}$ las causas pendientes en Sevilla.

En todo caso, lo que parece concluirse de este criterio de la apelación a la sede metropolitana -en estrecha relación con la centralidad del Obispo en la reforma y la cercanía a los fieles de la administración de justicia-, es que las circunstancias de hecho son muy distintas en Suramérica (al menos en México y Argentina) y en Europa (tomando como ejemplos, Alemania, Italia y España).

\section{La FUNCIÓN PROPIA DE LAS CONFERENCIAS EPISCOPALES}

El sexto criterio de la reforma hace referencia a la función propia de las Conferencias Episcopales, a quienes se les insta a que «respeten absolutamente el derecho de los obispos de organizar la potestad judicial en la propia iglesia particular». Asimismo, se les encomienda: «cuiden las Conferencias Episcopales que, en cuanto sea posible, y salvada la justa y digna retribución de los operadores de los tribunales, se asegure la gratuidad de los procesos, para que la Iglesia mostrándose a los fieles como madre generosa, en una materia tan estrechamente ligada a la salvación de las almas, manifieste el amor gratuito de Cristo, por el cual todos hemos sido salvados». De conformidad con estos dos criterios, el Subsidio aplicativo, recuerda que «respetando el derecho de los Obispos a organizar la potestad judicial en la propia Iglesia particular, las Conferencias episcopales tienen la obligación de ayudar, incluso económicamente donde esto es posible, a los Obispos a restaurar la cercanía entre la potestad judicial y los fieles, ya sea en el proceso ordinario como en el más breve. Ayudarán también, (...) a que sea asegurada, dentro de lo posible la gratuidad de los procedimientos» ${ }^{80}$.

\footnotetext{
79 Prot. n. 4713/13 SAT: Decreto de Prórroga de competencia otorgado por el Tribunal de la Signatura apostólica, el 5 de septiembre de 2013, que en entró en vigor el 1 de noviembre de 2013.

${ }^{80}$ Subsidio aplicativo, 12.
} 
En orden a aplicar el primer principio - que podríamos llamar negativo: no dificultar o inmiscuirse en las competencias de los obispos- la Comisión de trabajo constituida para la Conferencia Episcopal Italiana, ha declarado derogado el c. $1439^{81}$. El documento que se ha publicado como conclusión de esa mesa de trabajo contiene declaraciones como la siguiente $\ll$ Si intende abrogato il can. 1439 $\$ 1$ circa la competenza della Conferenza Episcopale in tema di tribunal di seconda instanza». Aunque el texto al que se hace referencia pueda ser considerado, a tenor del c. 16 interpretación auténtica del MI, sin embargo, no está clara su naturaleza ${ }^{82}$, por su contenido literal más bien parece una derogación de la ley universal precedente, por medio de una ley particular para Italia ${ }^{83}$. Esta interpretación está en continuidad con la derogación del Motu proprio Qua cura en Italia. A tenor del rescripto ex audientia de 7-XII-2015, I, las leyes de reforma del proceso matrimonial abrogan o derogan toda ley o norma contraria vigente hasta ahora, general, particular o especial, eventualmente también aprobada de forma específica (como por ejemplo el motu proprio Qua cura, dado por Pío XI en 1938). La Congregación de Sacramentos emitió unas normas para la ejecución de ese motu proprio que instituyeron en Italia los Tribunales eclesiásticos Regionales. El rescripto del Romano Pontífice reafirma la responsabilidad de cada obispo diocesano (c. $1673 \$ 1$ ) como juez de primera instancia en su diócesis, en el mismo sentido en el que se expresa la Instr. Dignitas connubii en el art. $22 \$ 1^{84}$.

${ }^{81}$ El CIC, prescribe en el c. $1439 \$ 1$. Si, de acuerdo con el c. 1423 , hay un solo tribunal de primera instancia para varias diócesis, la Conferencia Episcopal, con la aprobación de la Sede Apostólica, debe establecer un tribunal de segunda instancia, a no ser que todas aquellas diócesis sean sufragáneas de la misma archidiócesis.

$\$ 2$. La Conferencia Episcopal puede constituir uno o más tribunales de segunda instancia, con la aprobación de la Sede Apostólica, aun fuera de los casos previstos en el $\$ 1$.

$\$ 3$. Respecto a los tribunales de segunda instancia de que tratan los $\$ \$ 1-2$, la Conferencia Episcopal o el Obispo designado por ésta tienen todas las potestades que competen al Obispo diocesano sobre su tribunal.

82 J. LLOBELL, Cuestiones acerca de la apelación y la cosa juzgada..., 63, anota: «algunas normas del "Tavolo di lavoro" (20-VII-2016) pueden ser encuadrables como propias de un decreto general ejecutorio ex CIC c. 31, aunque también incluyen prescripciones cuya naturaleza puede ser considerada legislativa ex c. 29 (decreto general legislativo) o c. 30 (potestad legislativa delegada)».

${ }^{83}$ C. 20: La ley posterior abroga o deroga a la precedente, si así lo establece de manera expresa, o es directamente contraria a la misma, u ordena completamente la materia que era objeto de la ley anterior; sin embargo, la ley universal no deroga en nada el derecho particular ni el especial, a no ser que se disponga expresamente otra cosa en el derecho.

${ }^{84}$ Considera que sigue vigente la Instr. Dignitas Connubii en lo que no se oponga a la nueva normativa, R. RodRíGUEZ CHACón, Antecedentes, estructura y valor jurídico en el sistema normativo canónico de los dos Motu Propio de 15 de agosto de 2015 y sus normas anejas, en M. E. Olmos OrTEGa (ed.), Procesos de nulidad matrimonial tras la reforma del Papa Francisco, Madrid 2016, 57. 
No obstante, conviene recordar que el art. 18 de la Const. Pastor Bonus ${ }^{85}$, prevé que cuando una norma de un dicasterio contiene elementos innovadores, debe ser aprobada específicamente por el Romano Pontífice ${ }^{86}$, entiendo que la derogación del c. $1439 \$ 1^{87}$ que hace el escrito de 20 de julio de 2016, requiere la aprobación del Romano Pontífice ${ }^{88}$. Sería deseable que el documento emitido como fruto del trabajo de la Comisión constituida para la Conferencia Episcopal Italiana, contase con la aprobación específica del Romano Pontífice. Y se hiciese constar si esa derogación tiene o no ámbito universal ${ }^{89}$.

Por lo que se refiere al segundo aspecto (la contribución económica de las Conferencias Episcopales para lograr, en la medida de lo posible, la gratuidad de los procesos), sabemos que la Conferencia Episcopal de los Estados Unidos de América contribuye al sostenimiento de la Rota Romana. Quizá la aportación de la Conferencia Episcopal Española esté menos justificada, pues ya contribuye a sostener el Tribunal de la Nunciatura de la Rota de Madrid. Tal vez el impacto, por lo que se refiere a la gratuidad, en el territorio de la Conferencia Episcopal Española no es muy relevante, puesto que ya antes de la reforma se atendían por el patrocinio de justicia gratuita, a quienes no po-

85 «Han de someterse a la aprobación del Sumo Pontífice las decisiones de mayor importancia, a excepción de aquellas para las que se hayan atribuido a los dirigentes de dicasterios facultades especiales, y exceptuadas las sentencias del Tribunal de la Rota Romana y el Tribunal Supremo de la Signatura Apostólica, pronunciadas dentro de los límites de su respectiva competencia.

Los dicasterios no pueden emanar leyes o decretos generales que tengan fuerza de ley, ni derogar las prescripciones del derecho universal vigente, sino en casos determinados y con aprobación especifica del Sumo Pontífice.

Quede establecido que no se haga nada importante y extraordinario si los dirigentes de dicasterio no lo comunican antes al Sumo Pontífice».

${ }^{86}$ G. BONI, La recente riforma del proceso di nullità matrimoniale. Problemi, criticità, dubbi (parte prima)..., 47.

87 C. 1439 . 1. «Si, de acuerdo con el canon 1423, hay un solo tribunal de primera instancia para varias diócesis, la Conferencia Episcopal, con la aprobación de la Sede Apostólica, debe establecer un tribunal de segunda instancia, a no ser que todas aquellas diócesis sean sufragáneas de la misma archidiócesis.

2. La Conferencia Episcopal puede constituir uno o más tribunales de segunda instancia, con la aprobación de la Sede Apostólica, aun fuera de los casos previstos en el apdo. 1.

3. Respecto a los tribunales de segunda instancia de que tratan los apdos. 1-2, la Conferencia Episcopal o el Obispo designado por ésta tienen todas las potestades que competen al Obispo diocesano sobre su tribunal».

${ }^{88}$ F. J. URRUTia, «... Atque de specifica approbatione summi pontificis» (Const. Ap. «Pastor bonus», art. 18), Revista Española de Derecho Canónico 47 (1990) 543-561.

89 J. Llobell, Cuestiones acerca de la apelación y la cosa juzgada..., 64, anota, que a pesar de la «italianidad» del «Tavolo» (aquí hemos venido señalando a esta mesa de trabajo como Comisión), ello no impide que los temas tratados y decididos sean todos de interés para la Iglesia universal. 
dían afrontar los gastos del proceso ${ }^{90}$. Con posterioridad a la reforma, se aconseja que se pida a los fieles que acuden a los tribunales eclesiásticos y pueden pagar, que hagan un donativo para su sostenimiento ${ }^{91}$.

En España, la Conferencia Episcopal cuenta con una subcomisión de Familia y defensa de la vida ${ }^{92}$, que se debe considerar incluida dentro de las estructuras pastorales cuya conversión anima el MI, y que puede desempeñar un papel importante en orden a evitar que se celebren matrimonios nulos, pero no en orden a que se declaren nulos los inválidamente contraídos.

Algunos autores han propuesto que «para el futuro, debería plantearse el desdoblamiento del Libro VII del CIC 83 en diversas legislaciones territoriales» ${ }^{93}$. En mi opinión más que una diversificación del Derecho procesal por

90 «No obstante, se puede y se debe decir cuánto cuesta un proceso de nulidad en el tribunal interdiocesano de Aragón: aproximadamente 1.700 euros. A primera vista, puede parecer mucho, pero es una cantidad muy pequeña, si se considera que con ese dinero se paga al abogado, a los seis jueces que intervienen, al defensor del vínculo, al promotor de justicia, a los notarios y en algunos casos a los psicólogos, psiquiatras... En todo caso, hay personas que no pueden pagar esa cantidad y aportan la mitad. Otras no pagan nada. A nadie se deja de atender por problemas económicos». Así consta en la web del Tribunal interdiocesano de Aragón. Cfr.: $\mathrm{M}^{\mathrm{a}} \mathrm{J}$. RoCA, La reforma del proceso canónico de las causas de nulidad matrimonial: de las propuestas previas a la nueva regulación, Revista General de Derecho Canónico y Eclesiástico del Estado 40 (2016). Por lo que se refiere a la Archidiócesis de Madrid, el Arzobispado declaró por Decreto la gratuidad de todos los procesos de nulidad en su Tribunal (nota 72). Lo que hemos anotado sobre la provincia de Aragón respecto a la total gratuidad de los procesos de quienes no pueden afrontar los gastos, cabe extenderlo a la Provincia eclesiástica de Granada (nota 73) y de la Provincia eclesiástica de Santiago de Compostela (nota 74). En la página web del Arzobispado de Sevilla consta que las tasas del Tribunal ascienden a 985 euros, aportados en fracciones (presentación de la demanda, declaración del dubium, publicación y conclusión de la causa), si bien cabe la posibilidad de obtener el beneficio de justicia gratuita o semigratuita. En el documento de la web no figura exactamente el año o años en los que regían esas tasas. No nos consta que las medidas que han adoptado algunos Obispos tengan como fundamento la aportación económica de la Conferencia Episcopal. Cfr. J. Ortiz Herraiz, La gratuidad del proceso, Revista General de Derecho Canónico y Eclesiástico del Estado 41 (2016).

91 Subsidio aplicativo, 12, sugiere solicitar -según el prudente criterio de los pastores- a las partes con tacto pastoral una contribución para las causas de los pobres. En mi opinión, es preferible que quienes puedan contribuir, paguen tasas, y no hagan donativos, para evitar cualquier impresión de que la contribución económica influye en el fallo judicial.

92 La Subcomisión Episcopal de Familia y Vida basa su labor «en favor de quienes tienen derecho a nacer y a ser acogidos por sus padres con amor; hablamos en favor de las madres, que tienen derecho a recibir el apoyo social y estatal necesario para evitar convertirse en víctimas del aborto; hablamos en favor de la libertad de los padres y de las escuelas que colaboran con ellos para dar a sus hijos una formación afectiva y sexual de acuerdo con unas convicciones morales que los preparen de verdad para ser padres y acoger el don de la vida; hablamos en favor de una sociedad que tiene derecho a contar con leyes justas que no confundan la injusticia con el derecho».

93 S. Bueno SAlinas, La reforma de los procesos canónicos de declaración de nulidad de matrimonio. La celeridad del proceso..., 17. 
ámbitos territoriales, lo que sí parece oportuno tener en cuenta es la diversidad de competencias entre los distintos tribunales eclesiásticos, tanto por razón del territorio que comprenden, como por razón del número de fieles. Parece muy distinta la situación de los tribunales regionales en Italia que la de los tribunales interdiocesanos de México DF, Buenos Aires o Córdoba (Argentina).

\section{La APELACión a la SEDE Apostólica}

El mantenimiento de la apelación ante la Sede Apostólica, se basa tanto en un criterio histórico («respetando un antiguo principio jurídico», dice literalmente el M. P.), como sobre todo, reforzar el vínculo entre la Sede de Pedro y las Iglesias particulares. Conviene tener presente que antes de la reforma, cuando se pedía la supresión de la doble conforme, se consideraba que esta exigencia suponía una desconfianza hacia los tribunales inferiores (cfr. supra apartado 1). Las medidas de la reforma suponen una muestra de confianza en el trabajo de los tribunales inferiores. Por ello se ha dicho que un principio que subyace en esta reforma es la confianza.

¿Podría concluirse que del criterio IV (la apelación a la Sede Metropolitana) y el VII (la apelación a la Sede Apostólica), resulta conveniente la supresión del Tribunal de la Nunciatura Apostólica de Madrid? O dicho de otro modo, ¿la aplicación de estos criterios supone un riesgo para la pervivencia de la Rota de Madrid? A mi modo de ver, no se debe suprimir el Tribunal de la Nunciatura de Madrid, su mantenimiento no obsta para que quien lo desee pueda acudir a la Sede Apostólica, tanto antes como después de la reforma.

El Decano de la Rota Romana ha manifestado que la primera razón del proceso refundado por su Santidad del Papa Francisco ha sido la colegialidad, expresar su fidelidad a la teología del Concilio Vaticano II en este aspecto ${ }^{94}$. A la vista de las medidas adoptadas por la reforma y por las interpretaciones pos-

\footnotetext{
${ }^{94}$ P. V. PINTO, Trascrizione dell'intervento pronunciato alla conferenza stampa di presentazione delle due Lettere motu proprio datae di Papa Francisco en www.vatican.va: «Qual è, dunque, la novità dell'intervento di Papa Francisco? Vorrei riassumerla nei ppunti essenzziali. Egli fedele al Vaticano II ha inteso, nei suoi atti fin dall'inizio del suo pontificato, esprimere fedeltà alla teología della collegialità ddel Vaticcano II. La prima ratio del proceso che viene ora pubblicato è in ragione di questo princicpio: il Papa investe sulla collegialità, nella fiducia verso i vescovi». Puede verse en https://press.vatican.va/content/salastampa/it/bollettino/pubblico/2016/11/21/ 0840/01871.html. G. BONI, La recente riforma del proceso di nullità matrimoniale. Problemi, criticità, dubbi (parte prima)..., 59, nota 163.
} 
teriores que de ella se han hecho, cabe preguntarse si expresa mejor la colegialidad episcopal la existencia de tribunales diocesanos que la de tribunales regionales, como venían existiendo hasta ahora, en Italia sobre todo. Y en caso de respuesta afirmativa, por qué es así. Buena parte de las Conferencias episcopales regionales en Italia parecían estar satisfechas con el trabajo realizado por los tribunales regionales, al menos así consta de la Conferencia episcopal de Toscana ${ }^{95}$, de la de Puglia ${ }^{96}$ y otras como Piemonte, Triveneto, Lombardía, Campania y Cerdeña. Cuando se habla de colegialidad en este contexto judicial se trata del «afecto colegial», no de la colegialidad episcopal en sentido estricto, pues la colegialidad episcopal en sentido estricto no se ejerce ni siquiera a través de las Conferencias episcopales. Así quedó claro a partir de la exhortación Apostolos suos ${ }^{97}$. No se acaba de ver por qué es mejor expresión de la colegialidad episcopal la constitución de tribunales interdiocesanos, suprimiendo la intervención de la Conferencia Episcopal, que los tribunales regionales existentes hasta ahora. Salvando siempre, el deber de todos y cada uno de los Obispos diocesanos de juzgar personalmente los procesos breves sus propias diócesis. El recurso ante el metropolitano, o ante la Sede Apostólica o la eventual constitución de tribunales interdiocesanos son expresiones del afecto colegial. Pero por el mismo motivo pueden verse como tales los tribunales regionales o de primera y segunda instancia constituidos antes de la reforma.

La finalidad del MI es acortar la distancia que separa a los fieles de los tribunales de la Iglesia. En ocasiones la distancia es física (así por ejemplo el tribunal interdiocesano de Buenos Aires es el tribunal de primera instancia de 15 diócesis la más lejana está a unos $240 \mathrm{~km}$ de distancia ${ }^{98}$. Facilita el acceso a los tribunales eclesiásticos a muchos inmigrantes ${ }^{99}$.

${ }_{95}$ La Conferenza episcopale toscana il 1 febbraio ha scritto che è opportuno «non dileguare la rete di collaboratori e la positiva esperienza dei tribunali regionali».

${ }^{96}$ La Conferenza episcopale pugliese il 7 dicembre 2015, ancor prima della promulgazione ufficiale della riforma di Bergoglio, quando il testo era ormai conosciuto, aveva scritto che «l'Episcopato pugliese ritiene che l'esperienza e la competenza maturata nel corso di una storia pluridecennale, iniziata nel 1939, può garantire la più compiuta attuazione di quanto previsto dalla recente normativa pontificia». La stesse cose le hanno scritte i vescovi campani e sardi in due note del 1 dicembre. Il Sussidio della Santa Sede non ha risolto i problemi e l'opinione prevalente dell'episcopato italiano è rimasta quella dell'impossibilità di erezione di singoli tribunali diocesani.

97 J. R. ViLlar, La naturaleza de las Conferencias Episcopales y la Carta Apostolos suos, Scripta Theologica $31(1999 / 1) 115$ y ss.

98 R. Serres LóPEZ de GUEREÑu, El motu proprio «Mitis Iudex Dominus Iesus»..., 74-75.

99 R. Serres López de GuereÑU, El motu proprio «Mitis Iudex Dominus Iesus»..., 77. 
Para las diócesis metropolitanas españolas, el tribunal de apelación es el de la Nunciatura de Madrid o Rota de Madrid. En caso de que se produjera una ulterior apelación, porque no se producía en segunda instancia la confirmación del fallo emitido en la primera, el tribunal de tercera instancia es otro turno de jueces de la misma Rota de Madrid ${ }^{100}$. Para las diócesis sufragáneas españolas, la Rota es el tribunal de tercera instancia. Al haberse suprimido la exigencia de la doble sentencia conforme para que la nulidad sea ejecutiva, parece evidente que habrá muchas menos causas que lleguen a la Rota de Madrid. En mi opinión, ello no debería poner en cuestión su futura existencia, pues evita la sobrecarga de la Rota Romana. Tal vez una medida que pudiera agilizar la tramitación de las causas en las diócesis metropolitanas es que la Rota de Madrid fuera el tribunal de apelación de todas las causas en segunda y ulterior instancia, provengan de diócesis sufragánea o metropolitana. De este modo, los tribunales metropolitanos verían aliviada su carga de trabajo, pues no conocerían las apelaciones de los tribunales de las diócesis sufragáneas.

\section{CONSIDERACiONES FinAles}

Algunas de las modificaciones legislativas que se han introducido no tienen, a mi modo de ver, una justificación clara ni en estos seis criterios que se indican el preámbulo del Mitis Iudex, ni en los fines de la reforma (celeridad, gratuidad, y salus animarum). Así, por ejemplo, que el propio juez pueda dispensar de la ley procesal. A tenor de lo previsto en las facultades especiales concedidas por Benedicto XVI a la Rota Romana el 11 de febrero de 2013, el Decano de la Rota Romana ya tenía la potestad de dispensar por grave causa de las Normas Rotales en materia procesal. Esta facultad se mantiene en el rescripto ex audientia del Romano Pontífice Francisco (7XII-2015). La medida mencionada supone la anomalía de que el Derecho

${ }^{100}$ A día 11 de octubre de 2016, en el Tribunal de la Nunciatura de la Rota de Madrid, desde la entrada en vigor del MI han entrado 54 causas en el Tribunal ( 2 en 2015 y 52 en 2016). De ellas, a 21 causas no les afecta el MI, bien porque se tramitaban por el antiguo proceso breve del c. 1682, o bien porque están en tercera instancia y no hay diferencia en la tramitación (proceso ordinario). En cambio, a 33 causas sí les afecta el MI (de estas 33, son tramitadas en primera instancia 3, y 30 en segunda o ulterior instancia. Estos datos reflejan, a mi modo de ver, que no hay una sobrecarga excesiva en este Tribunal, si se compara con el número de causas anuales tramitadas en un tribunal de la jurisdicción civil. A la vez, supone un trabajo para la Iglesia en España. 
aplicable en la apelación puede ser distinto al de la primera instancia. Además, de que se trata de una facultad discrecional del juez, que para aquellas partes procesales que no se vean favorecidas por la dispensa en casos similares, puede constituir una lesión del principio de igualdad entre todos los fieles (c. 208 CIC 83).

La reforma de este motu proprio no es sólo del procedimiento, sino que ha supuesto también consecuencias importantes de carácter jurisdiccional, llevada a cabo a través de la resolución de las dudas que la aplicación de estas normas plantea, sin estar expresamente previstas en el texto del MI. El impacto de la reforma procesal ha sido mucho mayor en Italia que en el territorio de otras Conferencias episcopales (como Alemania o España), debido a la existencia de los Tribunales eclesiásticos regionales. Una prueba de que el impacto de la reforma es mayor en Italia que en los territorios de otras Conferencias Episcopales es que, hasta donde nuestro conocimiento alcanza, sólo allí ha sido necesario constituir una mesa de trabajo para estudiar el alcance de la reforma.

Las medidas tendentes a reforzar la responsabilidad del Obispo en su diócesis, nos parece que son claras y eficaces para obtener ese fin: tanto por los procesos en los que actúa como juez, como por la mayor discrecionalidad de la que goza para nombrar juez único y jueces laicos (sin compartir su responsabilidad con la Conferencia Episcopal). Ahora bien, esta mayor discrecionalidad en el nombramiento de jueces, puede ser considerada también como medida que favorece la colegialidad episcopal menos que las previsiones anteriores a la reforma. A partir de la reforma cada Obispo diocesano goza de mayor autonomía en su diócesis, sin necesidad de contar con la aprobación de la Conferencia episcopal, que es una estructura de gobierno, al servicio de la colegialidad y la comunión episcopal.

La ampliación del fuero competente para interponer la demanda de nulidad, facilita indudablemente el acceso de los fieles a los tribunales eclesiásticos, especialmente en la situación de globalización en la que vivimos, y en la que con frecuencia los cónyuges provienen de Diócesis de Conferencias episcopales distintas, ya no viven en el domicilio de la Diócesis en la que contrajeron matrimonio, etc. Esta modificación de los títulos de competencia contribuye a reducir el tiempo dedicado al trámite de admisión de la demanda ${ }^{101}$.

101 C. MorÁn Bustos, Retos de la reforma procesal de la nulidad del matrimonio, Ius Canonicum 56 (2016) 25 . 
Normalmente antes de la reforma los procesos duraban año y medio ${ }^{102}$, cuando el tiempo se ha dilatado es debido a la necesidad de practicar exhortos a tribunales en de diócesis con poca experiencia judicial o de territorios con los que resulta difícil comunicarse. Sin embargo, también supone un riesgo de distanciamiento del fiel respecto de su Obispo diocesano, especialmente si se tiene en cuenta que es fuero competente el del cuasi-domicilio ${ }^{103}$.

102 S. Bueno SALINAS, La reforma de los procesos canónicos de declaración de nulidad de matrimonio. La celeridad del proceso, Revista General de Derecho Canónico y Eclesiástico del Estado 40 (enero 2016) 2, afirma, sobre la base de su experiencia judicial, que normalmente se cumplen los plazos previstos en el c. 1453, que establece un límite de un año para la primera instancia y de seis meses para la segunda.

103 Advierte de los peligros del fuero competente del cuasi-domicilio C. PEÑa GarCía, La reforma de los procesos canónicos de nulidad matrimonial: el motu proprio «Mitis Iudex Dominus Iesus», Estudios Eclesiásticos 90 (2015) 639 y ss. C. Morán Bustos, Retos de la reforma procesal de la nulidad del matrimonio, Ius Canonicum 56 (2016) 25, anota el riesgo de que se produzca un «turismo procesal» hacia los tribunales más benévolos, provocando un «efecto embudo» que iría en detrimento de la celeridad de la tramitación de las causas. 


\section{Bibliografía}

Alenda Salinas, M., ¿ Nuevas causas de nulidad matrimonial canónica? El sentido del art. 14 S 1 de las reglas de procedimiento contenidas en la Carta Apostólica Mitis Iudex Dominus Iesus, Revista General de Derecho Canónico y Eclesiástico del Estado 40 (enero 2016) (RI $\$ 417076$ ).

Arroba Conde, M. J., El proceso más breve ante el Obispo, en L. RuANo EsPINA - C. GuZMán PÉREZ (eds.), Reforma de los procesos de nulidad y otras novedades legislativas de Derecho canónico y eclesiástico del Estado, Dykinson, Madrid 2017, 249-287.

—, La pastoral judicial y la preparación de la causa en el Motu Proprio Mitis Iudex Dominus Iesus, en M. E. Olmos OrTega (ed.), Procesos de nulidad matrimonial. Tras la reforma del Papa Francisco, Dykinson, Madrid 2016, 63-82.

Beal, J. P., Mitis Iudex Canons 1671-1682, 1688-1691. A commentary, The Jurist 75 (2015) 467-538.

BonI, G., La recente riforma del proceso di nullità matrimoniale. Problemi, criticità, dubbi (parte prima), Stato Chiese e pluralismo confessionale 9, 2016, www. statochiese.it.

—, La recente riforma del proceso di nullità matrimoniale. Problemi, criticità, dubbi (parte seconda), Stato Chiese e pluralismo confessionale 10, 2016, www.statochiese.it.

—, La recente riforma del proceso di nullità matrimoniale. Problemi, criticità, dubbi (parte terza), Stato Chiese e pluralismo confessionale 11, 2016, www.statochiese.it.

Bonnet, P. A., De iudicis sententia ac de certitudine morali, Periodica 75 (1986) 61-100.

Bueno Salinas, S., La reforma de los procesos canónicos de declaración de nulidad de matrimonio. La celeridad del proceso, Revista General de Derecho Canónico y Eclesiástico del Estado 40 (2016).

CEBRIÁ GARCÍA, $M^{\mathrm{a}} \mathrm{D}$., Las circunstancias y hechos orientativos de la nulidad clara del art. 14 del Motu Proprio Mitis Iudex Dominus Iesus, para abrir el proceso breve ante el Obispo, Revista General de Derecho Canónico y Eclesiástico del Estado 40 (2016).

De Bertolis, O., Papa Francesco riforma il processo canonico matrimoniale, Quaderno 3967 del 10-X-2015 (Civ. Catt. IV 3-102), 59-68.

ERDÖ, P., La certeza morale nella pronuncia del giudice. Problemi attuali, Periodica 87 (1998) 81-104. 
FERRER OrTiz, J., Valoración de las circunstancias que pueden dar lugar al proceso abreviado, Ius Canonicum 56 (2016) 157-192.

Fumagalli Carulli, O., Celerità della via giudiziaria e pastorale di prossimità nella riforma del processo matrimoniale canonico, Ius Vita e Pensiero, publicado el 1-VI-2016 accesible en http://jus.vitaepensiero.it/news-papers-celerita-della-via-giudiziaria-e-pastorale-di-prossimita-nella-riforma-del-processo-matrimoniale-canonico-4660.html.

Grocholewski, Z., La certezza morale come chiave di lettura delle norme processuali, Ius Eclesiae 9 (1997) 417-450.

Hack, M. A., Tribunal interdiocesano, en J. Otaduy - A. Viana - J. Sedano (dirs.), Diccionario General de Derecho Canónico, VII, Thomson Reuters Aranzadi, Cizur Menor (Navarra) 2012, 674-676.

Heredia Esteban, F., El proceso más breve ante el Obispo, Anuario de Derecho Canónico supl. 5 (2016) 97-122.

Huber, J., Die moralische Gewissheit des Richters (c. 1608 CIC/1983), De Processibus matrimonialibus 21/22 (2014/15) 377-396.

LLOBELl, J., La certeza morale nel proceso canonico, Il Diritto ecclesiastico 109/1 (1998) 758-802.

—, Novità procedurali riguardanti la Rota Romana: le facoltà speciali, Stato, Chiese e pluralismo confessionale 32, 2013, www.statochiese.it.

—, Los procesos matrimoniales en la Iglesia, Rialp, Madrid 2014.

—, El ejercicio personal de la potestad judicial del Obispo diocesano. Algunas consideraciones preliminares al M.p. «Mitis Iudex» y al M.p. «Mitis et Misericors», Revista General de Derecho Canónico y Eclesiástico del Estado 41 (2016).

-, Cuestiones acerca de la apelación y la cosa juzgada en el nuevo proceso de nulidad del matrimonio, Anuario de Derecho Canónico supl. 5 (2016) 53-95.

López Medina, A. $\mathrm{M}^{\mathrm{a}}$, Precedentes mediatos e inmediatos de una esperada reforma de las causas matrimoniales, Revista General de Derecho Canónico y Eclesiástico del Estado 40 (2016).

Martens, K., Signatura Apostólica Tribunal de la, en J. Otaduy - A. Viana J. Sedano (dirs.), Diccionario General de Derecho Canónico, vol. VII, Thomson Reuters Aranzadi, Cizur Menor (Navarra) 2012, 310-314.

Moneta, P., Prolusione del Prof. Avv. Rot. Paolo Moneta al Tribunale Ecclesiastico Regionale Umbro, en http://www.tribunaleecclesiasticoumbro.it/index.php? option=com_content $\&$ view $=$ article $\& \mathrm{id}=136$ :prolusione-profpaolo-moneta\&catid=39:diesannualis\&Itemid=123 Consulta del 2 de febrero de 2017. 
Morán Bustos, C., El proceso «brevior» ante el Obispo Diocesano: requisitos procesales y sustantivos de un proceso que ba de ser extraordinario, Revista General de Derecho Canónico y Eclesiástico del Estado 41 (2016).

-, Retos de la reforma procesal de la nulidad del matrimonio, Ius Canonicum 56 (2016) 9-40.

-, Derecho a la verdad: diligencia y celeridad en el proceso matrimonial canónico, en N. Álvarez de las Asturias (ed.), En la salud y en la enfermedad. Pastoral $y$ derecho al servicio del matrimonio, Cristiandad, Madrid 2015, 159-252.

—, El proceso «brevior» ante el Obispo, en M. E. Olmos Ortega (ed.), Procesos de nulidad matrimonial. Tras la reforma del Papa Francisco, Dykinson, Madrid 2016, 125-176.

—, El proceso «brevior» ante el Obispo Diocesano: requisitos procesales y sustantivos de un proceso que ha de ser extraordinario, Revista General de Derecho Canónico y Derecho Eclesiástico del Estado 41 (2016) 1-52.

-, Retos de la reforma procesal de la nulidad del matrimonio, en L. RUANO EsPINA - C. GUZMán PÉREZ (eds.), Reforma de los procesos de nulidad y otras novedades legislativas de Derecho canónico y eclesiástico del Estado, Dykinson, Madrid 2017, 205-247.

Moreno García, P. A., El servicio de indagación prejudicial: aspectos jurídico-pastorales, Ius Canonicum 56 (2016) 65-85.

NaVARro VAlLs, R., Los fundamentos de la sentencia canónica, Ius canonicum 15 (1975) 303-329.

NúÑEZ, G., El proceso brevior: exigencias y estructura, Ius Canonicum 56 (2016) 135-155.

OchoA, X., Leges Ecclesiae post Codicem Iuris Canonici editae. Vol. 4, Leges annis 1969-1972 editae, Commentarium Religiosis, Institutum Iuridicum Claretianum, Romae 1974.

Olmos Ortega, M. E., Laicos y oficios eclesiásticos, Revista Española de Derecho Canónico 58 (2001) 557-575.

—, La participación de laicos en los órganos de gobierno de la Iglesia (con especial referencia a la mujer), Revista Española de Derecho Canónico 46 (1989) 89-114.

—, Le dichiarazioni delle parti e la certezza morale, Ius Ecclesiae 18 (2006) 387416.

Ortiz, M. Á., Fe y matrimonio, en J. Bosch (ed.), Cuestiones actuales Derecho canónico y Derecho eclesiástico del Estado, Dykinson, Madrid 2015, 267 y ss.

Ortiz Herraiz, J., La gratuidad del proceso, Revista General de Derecho Canónico y Eclesiástico del Estado 41 (2016). 
Panizo Orallo, S., Proceso documental, en J. Otaduy - A. Viana - J. Sedano (dirs.), Diccionario General de Derecho Canónico, vol. VI, Cizur Menor (Navarra) 2012, 515-520.

Paprocki, Th. J., Implementation of «Mitis Iudex Dominus Iesus» in the Diocese of Springfield in Illinois, The Jurist 75 (2015) 593-605.

PeÑa García, C., Agilización de los procesos canónicos de nulidad matrimonial: de las propuestas presinodales al motu proprio Mitis Iudex Dominus Iesus y retos pendientes tras la reforma, Ius Canonicum 56 (2016) 41-64.

—, La reforma de los procesos canónicos de nulidad matrimonial: el motu proprio «Mitis Iudex Dominus Iesus», Estudios Eclesiásticos 90 (2015) 621-682.

—, «Facultades especiales» del Decano y novedades procesales en la Rota Romana. ¿Hacia una renovación de las causas de nulidad matrimonial?, Estudios Eclesiásticos 88 (2013) 767-813.

—, El nuevo proceso «breviore coram episcopo» para la declaración de la nulidad matrimonial, Monitor Ecclesiasticus 130 (2015) 567-593.

REgORDÁn BARBERO, F. J., La investigación preliminar en las nuevas normas procesales del M. P. 'Mitis Iudex Dominus Iesus', Anuario de Derecho Canónico supl. 5 (2016) 39-52.

Roca, $\mathrm{M}^{\mathrm{a}} \mathrm{J}$., La reforma del proceso canónico de las causas de nulidad matrimonial: de las propuestas previas a la nueva regulación, Revista General de Derecho Canónico y Eclesiástico del Estado 40 (2016).

RodríGuez Chacón, R., La ejecutividad de las sentencias afirmativas de nulidad de matrimonio no apeladas, Revista General de Derecho Canónico y Eclesiástico del Estado 40 (2016).

—, El Rescriptum ex audientia SS. MI. de 11 de febrero de 2013, Revista General de Derecho Canónico y Eclesiástico del Estado 34 (2014).

-, Antecedentes, estructura y valor jurídico en el sistema normativo canónico de los dos Motu Propio de 15 de agosto de 2015 y sus normas anejas, en M. E. Olmos Ortega (ed.), Procesos de nulidad matrimonial tras la reforma del Papa Francisco, Madrid 2016, 17-62.

—, Nueva regulación de los procesos de nulidad matrimonial, Scripta Theologica 48 (2016) 295-331.

-, Mitis Iudex: Fuero competente y sistema de apelaciones, Ius Canonicum 56 (2016) 105-134.

Ros CórColes, J., El vicario judicial y el instructor en los procesos de nulidad matrimonial tras el motu proprio Mitis Iudex, Ius Canonicum 56 (2016) 87103. 
SERres LóPez DE GuereÑu, R., El motu proprio «Mitis Iudex Dominus Iesus»: un servicio de misericordia y de verdad, Ius Communionis 4 (2016) 71-102.

Tavani, A. P., Fede e consenso matrimoniale, Torino 2013.

Tribunale Apostolico della Rota Romana, Sussidio aplicativo del Mot. Pr. Mitis Iudex Dominus Iesus, Cità del Vaticano 2016.

URrutia, F. J., «... Atque de specifica approbatione summi pontificis» (Const. Ap. «Pastor bonus», art. 18), Revista Española de Derecho Canónico 47 (1990) 543-561.

VIANA, A., El problema de la participación de los laicos en la potestad de régimen. Dos vias de solución, Ius Canonicum 54 (2014) 603-638.

VILlar, J. R., La naturaleza de las Conferencias Episcopales y la Carta Apostolos suos, Scripta Theologica 31 (1999/1) 115-137. 
